\title{
Synovial sarcoma of the maxillary sinus: an extremely rare case with excellent response to chemotherapy
}

\author{
Shin Saito' \\ Hiroyuki Ozawa' \\ Yuuichi Ikari' \\ Nana Nakahara' \\ Fumihiro Ito $^{2}$ \\ Mariko Sekimizu' \\ Junichi Fukada ${ }^{3}$ \\ Kaori Kameyama ${ }^{4}$ \\ Kaoru Ogawa' \\ 'Department of \\ Otorhinolaryngology - Head and \\ Neck Surgery, Keio University, \\ School of Medicine, ${ }^{2}$ Department of \\ Otorhinolaryngology - Head and \\ Neck Surgery, NHO Tokyo Medical \\ Center, ${ }^{3}$ Department of Radiology, \\ ${ }^{4}$ Department of Pathology, Keio \\ University, School of Medicine, \\ Tokyo, Japan
}

This article was published in the following Dove Press journal:
OncoTargets and Therapy

\begin{abstract}
This paper presents an extremely rare case of synovial sarcoma arising from the maxillary sinus, which resulted in a clinically complete response to chemotherapy. Synovial sarcoma is a rare soft tissue malignant tumor, most commonly affecting the extremities. While $\sim 10 \%$ occur in the head and neck region, synovial sarcoma of the sinonasal tract is extremely rare, with only 11 cases having been reported previously. As with other sarcomas, the standard treatment is complete resection while allowing for a safe margin, but this is often difficult in the head and neck area due to the complicated anatomy there. This makes the treatment of head and neck sarcoma challenging and leads to the need for a multimodal approach in advanced cases. However, the exact efficacy of chemotherapy is not well understood. In this report, we present a case of unresectable maxillary sinus synovial sarcoma that was successfully treated by chemotherapy followed by radiation therapy. A 53-year-old Japanese man was referred to our hospital with a history of left nose obstruction over the previous couple of years. Computed tomography/magnetic resonance imaging revealed a tumor arising from the maxillary sinus that extended to adjacent tissues. A biopsy was performed, and the tumor was diagnosed as synovial sarcoma. Since the tumor was unresectable, neoadjuvant chemotherapy was administered. The response was excellent, and the tumor became undetectable under endoscopy and radiological imaging. This provided us with a clinical evaluation of "complete response". The treatment was concluded with definitive radiotherapy and two more cycles of adjuvant chemotherapy. The patient remains free of disease 12 months after treatment. Synovial sarcoma of the head and neck is a rare entity; complete resection is the treatment of choice but (neo)adjuvant chemotherapy can be considered in unresectable cases, as we show here in the present case.
\end{abstract}

Keywords: sinonasal synovial sarcoma, adjuvant chemotherapy, synovial sarcoma, ifosfamide, pirarubicin

\section{Introduction}

Synovial sarcoma is a rare soft tissue malignant tumor accounting for $5 \%-10 \%$ of all adult soft-tissue sarcomas. ${ }^{1}$ The extremities are the most common site, but it can occur anywhere in the body. About 5\%-12\% of synovial sarcomas arise in the head and neck region, ${ }^{2-4}$ of which the paraspinal neck is considered the most common site. ${ }^{5}$ It mainly affects patients in their third decade, ${ }^{2-4,6}$ and the male-to-female ratio is equal, ${ }^{2,6}$ or slightly more in favor of men. ${ }^{3,4}$ Synovial sarcoma is considered a highgrade malignant tumor, and the 5-year overall survival rates have been reported to be $44.6 \%-61 \% .^{2,3,7}$ Head and neck lesions seem to have the same or slightly better prognosis, with 5 -year overall survival rates of $47 \%-81.6 \% .^{5-9}$
Correspondence: Shin Saito

Department of Otorhinolaryngology Head and Neck Surgery, Keio University, School of Medicine, 35, Shinanomachi, Shinjuku-ku, Tokyo 1608582, Japan

Tel +8| 33353 |2 I I

Fax $+8|33353| 26 \mid$

Email saitoshin3@gmail.com 
Standard treatment is complete resection, while the efficacy of adjuvant radiotherapy and chemotherapy has been studied. However, the response to chemotherapy in the head and neck region has not been reported in detail, and, to the best of our knowledge, this is the first report to discuss a case of synovial sarcoma arising in the maxillary sinus with a complete response to chemotherapy.

\section{Case report}

A 53-year-old Japanese man was referred to our hospital with a history of left nose obstruction over the previous couple of years. A soft mass was observable from the left vestibule of his nose. Physical examination revealed no neurological deficits. Computed tomography (CT) scan of the paranasal sinuses revealed opacification in the left maxillary sinus, ethmoid sinus, and frontal sinus. The posterolateral wall of the maxillary sinus was invaded, and the mass had progressed into the pterygopalatine fossa and infratemporal fossa. No lymph node swelling was identified (Figure 1A and B). Magnetic resonance imaging (MRI) of the paranasal scan revealed a heterogeneously enhancing mass in the left maxillary sinus, expanding into the common nasal meatus. The ethmoid sinus and frontal sinus were filled with high T2 lesions, arousing our suspicion of secondary sinusitis due to the tumor (Figure 1C and D).

Microscopic examination of a biopsy sample from the tumor showed small round cells, giving a preliminary report of olfactory neuroblastoma. However, this was unlikely
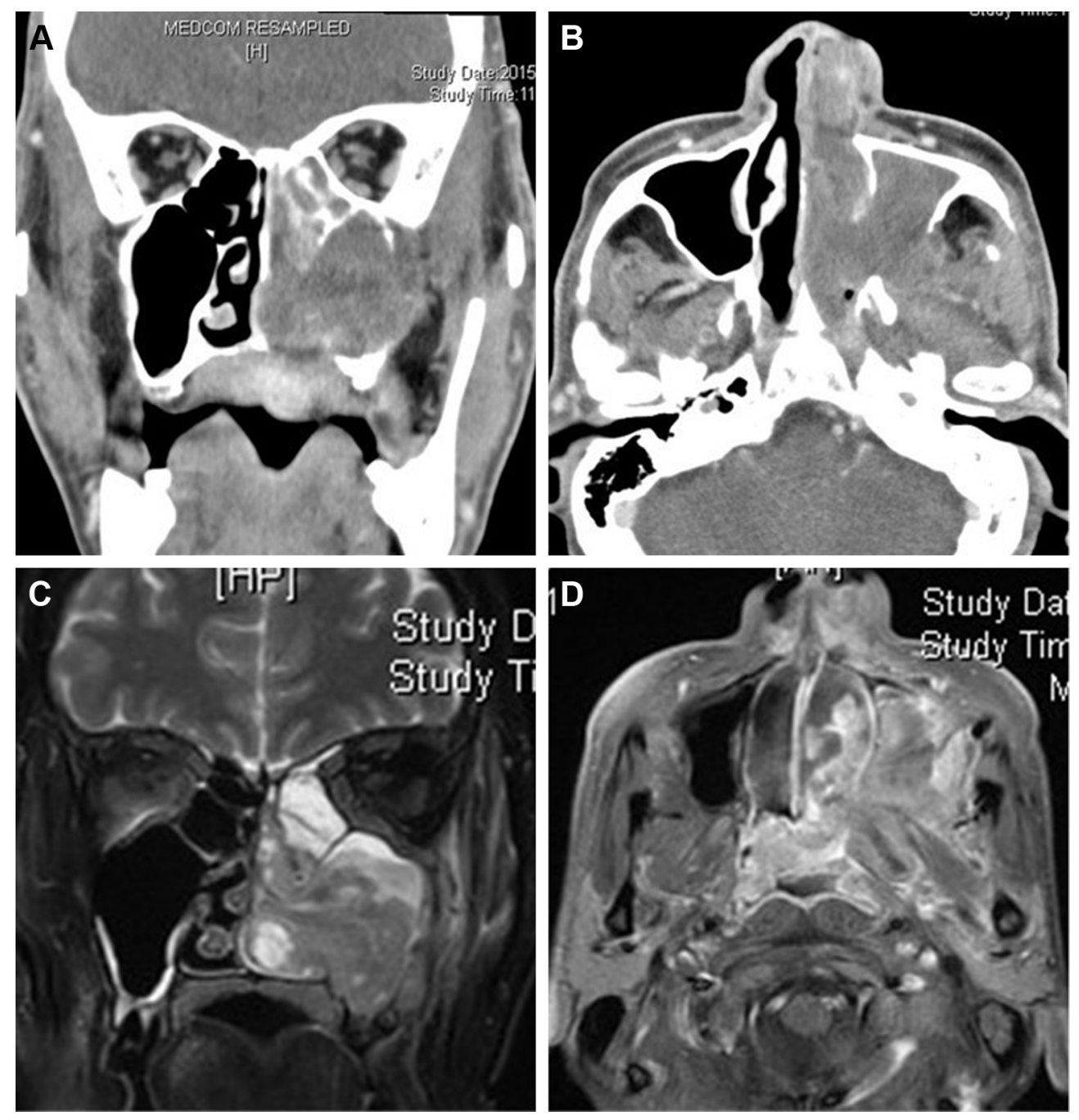

Figure I Pretreatment radiological imaging.

Notes: (A) Coronal view of enhanced CT. Opacification of the left maxillary sinus, ethmoid sinus, and sphenoid sinus is revealed. (B) Axial view of enhanced CT. The posterolateral wall of the maxillary sinus is invaded and destroyed. (C) Coronal view of T2-weighted imaging. The tumor expands from the maxillary sinus to the common nasal meatus. The ethmoid sinus and nasofrontal duct are filled with secondary sinusitis. (D) Axial view of Gd enhanced TI-weighted imaging. The tumor extends posterior-laterally, invading the medial and lateral pterygoid muscles.

Abbreviation: $\mathrm{CT}$, computed tomography. 
since the olfactory cleavage seemed to be unaffected and the main part of the tumor seemed to arise from the maxillary sinus. For a further definitive diagnosis, tumor resection under general anesthesia was performed. The mass was very soft and vascularized. Only the tumor of the common nasal meatus was removed for diagnosis, while the paranasal sinuses were left untouched. Post-operative histopathological examination revealed spindle cells and small round cells with ovoid hyperchromatic nuclei arranged in cellular sheets (Figure 2A and B). Immunohistochemically, the tumor cells were diffusely reactive for CD56, TLE1 (Figure 2C), INI-1 (Figure 2D), Bcl-2, and focally reactive for AE1/AE3, EMA, and desmin. The tumor was not immunoreactive for chromogranin A, synaptophysin, S-100, CD34, SMA, HMB-45, CD99, CD45, and GFAP, and in situ hybridization for EBER was negative. The morphological and immunohistochemical features were characteristics of biphasic synovial sarcoma.

Since the tumor was difficult to remove with a safe margin, we chose to deliver neoadjuvant chemotherapy. We referred to the JCOG0304 regimen, ${ }^{10}$ which is a perioperative chemotherapy regimen originally reported to be effective for high-grade sarcomas (including synovial sarcomas) in the extremities. The original regimen is doxorubicin $30 \mathrm{mg} / \mathrm{m}^{2} /$ day (days 1 and 2) + ifosfamide $2 \mathrm{~g} / \mathrm{m}^{2} /$ day (days $1-5$ ), but in order to reduce the adverse effects from doxorubicin, we used pirarubi$\operatorname{cin} 30 \mathrm{mg} / \mathrm{m}^{2} /$ day (days 1 and 2) instead. The patient received three courses of triweekly chemotherapy, which proved to be extremely effective, as we were able to observe that the tumor reduced in size after every course. After three cycles, the tumor was undetectable using fiberscopes and MRI, thus providing a response evaluation of "complete" (Figure 3 ). For definitive treatment, intensity-modulated radiotherapy of the maxillary sinus and the adjacent tissues was conducted with a total dose of 66 Gy in 33 fractions. Intensity-modulated radiation therapy was used, and, fortunately, radiation to the eye was spared, as the main part of the tumor was thought to be the posterior wall of the maxillary sinus, and there was no evidence of invasion into the orbit or the inferior wall. After radiotherapy, we delivered another two cycles of the initial regimen and concluded our treatment. The patient remains free of disease 12 months after therapy.

The main adverse events due to chemotherapy were leukopenia (grade 3, courses 1-5), neutropenia (grade 4, courses 1-5), and febrile neutropenia (grade 3, course 3 ). The patient required subcutaneous G-CSF (granulocyte-colony stimulating factor) injection every course. No cardiac-related events
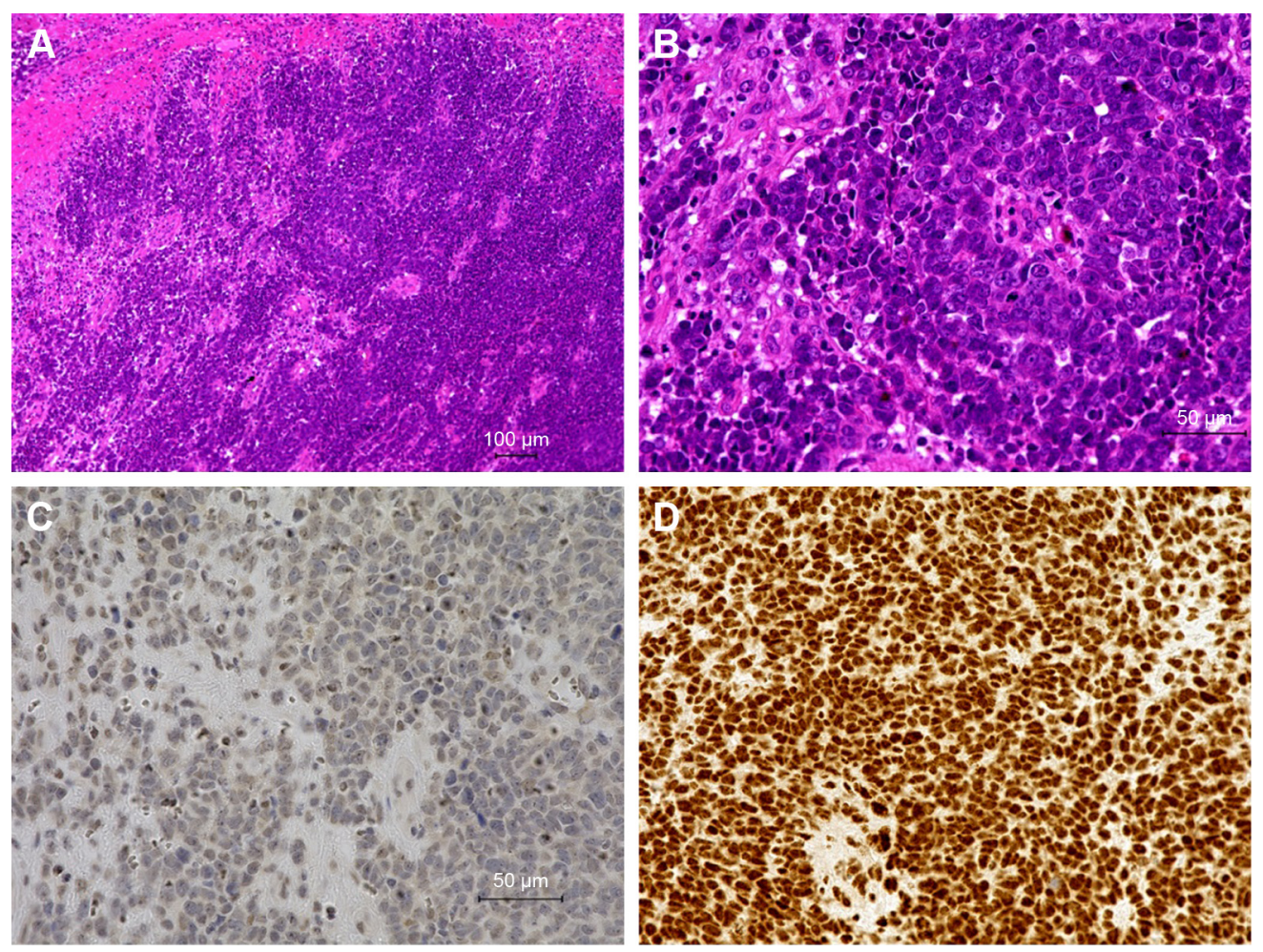

Figure 2 (A and B) Hematoxylin-eosin stain revealed spindle cells and small round cells with ovoid hyperchromatic nuclei arranged in cellular sheets. (Original magnification A: $\times 100$, B: $\times 400$.) Immunohistochemically, the tumor cells were diffusely reactive for TLEI (C) and INI-I (D). 

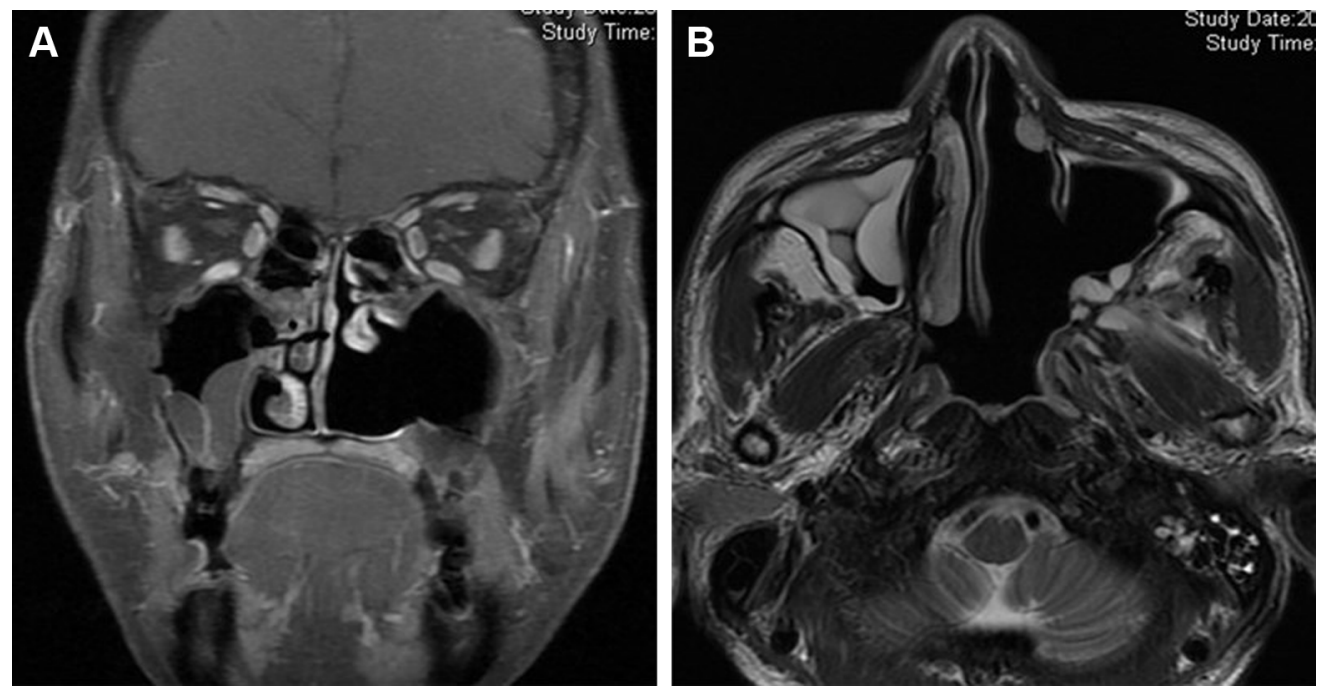

Figure 3 Magnetic resonance imaging after three courses of ifosfamide and pirarubicin.

Notes: No residual tumor can be identified. (A) Coronal view of Gd-enhanced TI-weighted imaging. (B) Axial view of T2-weighted imaging.

or hemorrhagic cystitis was observed. The adverse event due to radiation was grade 2 mucositis.

\section{Consent}

Written informed consent for publication of this report and images was obtained from the patient.

\section{Discussion}

As with other soft tissue malignancies, complete resection is considered the standard treatment for synovial sarcoma and has been reported to be an individual prognostic factor for local recurrence ${ }^{3}$ and overall survival ${ }^{7}$ mainly in extremity cases. However, in the head and neck region, it is sometimes difficult to completely resect the tumor with a safe margin. Even if it is operatively resectable, wide surgical resection can cause not only cosmetic and functional deterioration but also elevate the risk of perioperative complications. In such cases, chemotherapy has a chance of decreasing the size of the tumor and making the definitive therapy more effective, as we show here in the present case.

Synovial sarcoma is known to have a relatively good response to chemotherapy. This is based on several studies in the 1990s that reported a surprisingly good response to ifosfamide-based chemotherapy. ${ }^{11,12}$ From these findings and subsequent studies, ifosfamide (+doxorubicin)-based chemotherapy has generally been considered first-line treatment for patients with metastatic synovial sarcoma. As far as resectable, non-metastatic synovial sarcomas in the extremities are concerned, it has been reported that neoadjuvant chemotherapy (mesna/adriamycin/ifosfamide/dacarbazine) decreases distant metastasis and improves survival time, ${ }^{13}$ while adjuvant chemotherapy has been reported to lead to a slight but definite risk reduction in local recurrence, distant recurrence, and overall recurrence. ${ }^{14}$ From another study, ${ }^{15}$ it seems that locally aggressive tumors benefit more from chemotherapy than those which are not. However, despite these positive reports, the long-term benefit of chemotherapy on survival is still controversial. ${ }^{16}$

Due to the limited number of cases, the efficacy of chemotherapy on head and neck lesions is also obscure. From a case review of 44 patients by Gopalakrishnan et al, ${ }^{17}$ chemotherapy (where most patients received a combination of doxorubicin and ifosfamide) had no apparent advantage on overall survival. From a similarly limited data set, Crowson et al ${ }^{18}$ also could not find any survival benefits from delivering chemotherapy. An expert review ${ }^{19}$ also concluded that the data were insufficient to standardize the use of chemotherapy in head and neck synovial sarcomas. However, since the behavior of the tumor in the extremities and other areas seems to be quite similar, ${ }^{8}$ it is reasonable to assume that head and neck synovial sarcomas have a good chance of benefiting from chemotherapy, as in the above-mentioned reports. ${ }^{13-15}$ Especially, in those patients with locally aggressive and unresectable tumors in the head and neck region, chemotherapy has a chance of maximizing local control and decreasing the risk of distant metastasis.

We were able to review 11 cases of sinonasal synovial sarcoma from the literature, ${ }^{20-30}$ as summarized in Table 1. Patients were between 12 and 80 years of age, with an average age of 38 years and a male-to-female ratio of 7:4. All cases underwent surgery, with six cases receiving adjuvant 
Table I Demographics of patients with synovial sarcoma in the sinonasal tract

\begin{tabular}{|c|c|c|c|c|c|c|c|c|}
\hline $\begin{array}{l}\text { Author, } \\
\text { year }\end{array}$ & $\begin{array}{l}\text { Age, } \\
\text { sex }\end{array}$ & Site & Size & Histology & $\begin{array}{l}\text { Initial treatment } \\
\text { (procedure) }\end{array}$ & RTx (Gy/fractions) & $\begin{array}{l}\text { CTx } \\
\text { (drug) }\end{array}$ & $\begin{array}{l}\text { Outcome } \\
\text { (follow-up period) }\end{array}$ \\
\hline Trible, $1970^{20}$ & $24, \mathrm{~F}$ & Sphenoid & NR & NR & Surgery (NR) & Yes (NR) & No & Died due to disease ( 2 years) \\
\hline $\begin{array}{l}\text { Cihak et al, } \\
1997^{21}\end{array}$ & $25, M$ & Maxillary & NR & MPSS & $\begin{array}{l}\text { Surgery } \\
\text { (craniofacial } \\
\text { resection) }\end{array}$ & Yes (NR) & Yes (NR) & $\begin{array}{l}\text { Recurrence after } 2 \text { years and } \\
\text { underwent wide excision }\end{array}$ \\
\hline $\begin{array}{l}\text { Rangheard } \\
\text { et al, 200I }{ }^{30}\end{array}$ & $12, M$ & Maxillary & NR & NR & Surgery (NR) & Yes (NR) & Yes (NR) & $\begin{array}{l}\text { No evidence of disease } \\
\text { (10 years) }\end{array}$ \\
\hline $\begin{array}{l}\text { Kartha and } \\
\text { Bumpous, } \\
2002^{25}\end{array}$ & $24, \mathrm{~F}$ & Ethmoid & $6 \times 4 \times 3 \mathrm{~cm}$ & MPSS & Surgery (NR) & $\begin{array}{l}\text { Yes }(8,600 \text { cGy after } \\
\text { recurrence/NR) }\end{array}$ & Yes (NR) & $\begin{array}{l}\text { Died due to disease } \\
\text { ( } 9 \text { months). Metastasis to } \\
\text { lung and meninges }\end{array}$ \\
\hline Sun, $2003^{28}$ & $54, M$ & Maxillary & NR & BPSS & $\begin{array}{l}\text { Surgery (total } \\
\text { maxillectomy) }\end{array}$ & Yes (NR) & No & $\begin{array}{l}\text { No evidence of disease } \\
\text { ( } 45 \text { months) }\end{array}$ \\
\hline $\begin{array}{l}\text { Bettio et al, } \\
2004^{22}\end{array}$ & $36, M$ & Sphenoid & $5 \mathrm{~cm}$ & MPSS & Surgery (NR) & No & No & $\begin{array}{l}\text { Died I week after surgery } \\
\text { due to vascular complications }\end{array}$ \\
\hline $\begin{array}{l}\text { Gallia et al, } \\
2005^{23}\end{array}$ & $44, M$ & Frontal & $3.3 \times 2.5 \mathrm{~cm}$ & MPSS & $\begin{array}{l}\text { Surgery } \\
\text { (craniotomy) }\end{array}$ & Yes (6, I 20 Gy/NR) & Yes (MAl) & $\begin{array}{l}\text { No evidence of disease } \\
\text { ( } 2 \text { months) }\end{array}$ \\
\hline $\begin{array}{l}\text { Yildirim et al, } \\
2005^{24}\end{array}$ & $52, \mathrm{~F}$ & $\begin{array}{l}\text { Nasal } \\
\text { septum }\end{array}$ & $1.5 \times 1.5 \mathrm{~cm}$ & MPSS & $\begin{array}{l}\text { Surgery } \\
\text { (resection) }\end{array}$ & No & No & $\begin{array}{l}\text { No evidence of disease } \\
\text { (18 months) }\end{array}$ \\
\hline $\begin{array}{l}\text { Subramania } \\
\text { et al, } 2012^{26}\end{array}$ & $45, M$ & Sphenoid & $3.3 \mathrm{~cm}$ & PDSS & Surgery (biopsy) & No & Yes (NR) & NR \\
\hline $\begin{array}{l}\text { Salcedo- } \\
\text { Hernandez } \\
\text { et al, } 2013^{7}\end{array}$ & $26, M$ & Maxillary & $4 \mathrm{~cm}$ & NR & Surgery (NR) & No & No & $\begin{array}{l}\text { Died due to disease } \\
\text { (119 months) }\end{array}$ \\
\hline $\begin{array}{l}\text { Wong et al, } \\
2014^{27}\end{array}$ & $80, \mathrm{~F}$ & Ethmoid & NR & MPSS & $\begin{array}{l}\text { Surgery } \\
\text { (endoscopic } \\
\text { resection) }\end{array}$ & No & No & $\begin{array}{l}\text { Died due to disease } \\
\text { ( } 9 \text { months) } \\
\text { Metastasis to brain and } \\
\text { lymph nodes. }\end{array}$ \\
\hline Present case & $53, M$ & Maxillary & $5.0 \times 5.8 \mathrm{~cm}$ & BPSS & Surgery (biopsy) & Yes $(6,600$ cGy/33) & Yes (PI) & $\begin{array}{l}\text { No evidence of disease } \\
\text { (12 months) }\end{array}$ \\
\hline
\end{tabular}

Abbreviations: RTx, radiotherapy; CTx, chemotherapy; NR, not recorded; MPSS, monophasic synovial sarcoma; BPSS, biphasic synovial sarcoma; PDSS, poorly differentiated synovial sarcoma; MAl, mesna/doxorubicin/ifosfamide; PI, pirarubicin/ifosfamide; M, male; F, female.

radiotherapy and five cases receiving chemotherapy as adjuvant treatment or after distant metastasis, while none received neoadjuvant chemotherapy. Four cases were treated with surgery alone, while the remaining seven had surgery plus radiotherapy and/or chemotherapy. Of the five cases that received chemotherapy, Gallia et $a^{23}$ were the only ones to describe the regimen in detail (three cycles of mesna/doxorubicin/ ifosfamide), but the response to the therapy was not clearly stated. The average follow-up period was $<3$ years, and four out of the 11 cases died within 2 years. One case died due to postoperative vascular complication.

Notwithstanding the accumulative data showing the positive effect of using chemotherapy, caution is required with respect to side effects. Side effects can be so significant that one report suggested that the use of chemotherapy should be restricted to cases with poor prognosis ${ }^{7}$ (tumor size over $5 \mathrm{~cm}$, evidence of local extension on presentation, or a highrisk site of presentation). The regimen we used this time also encountered a number of side effects, especially leukopenia and neutropenia. According to Tanaka's original report, ${ }^{10}$
$97.2 \%$ of patients were observed to have grade 3 or 4 leukopenia, $98.6 \%$ neutropenia, and $18.1 \%$ febrile neutropenia. In the present case, we encountered grade 3 leukopenia and grade 4 neutropenia every five cycles. Fortunately, febrile neutropenia was observed only once. Administration of subcutaneous G-CSF for 4-5 days allowed the patient to recover promptly from neutropenia, and there was no delay of treatment due to these significant toxicities. However, because of this, we strongly recommend that this regimen be managed in an inpatient situation.

The case we present here is only a case report, and the follow-up period is still very short. As with synovial sarcomas of the extremities, metastasis or local recurrence can occur after a certain period, and we are currently following-up the present patient very closely. We hope more data concerning the use of chemotherapy on head and neck lesions are reported and that the benefit is clearly revealed.

\section{Disclosure}

The authors report no conflicts of interest in this work. 


\section{References}

1. Enzinger FM, Weiss SW. Soft Tissue Tumours. Chicago: Mosby Inc; 2001.

2. Shi W, Indelicato DJ, Morris CG, Scarborough MT, Gibbs CP, Zlotecki RA. Long-term treatment outcomes for patients with synovial sarcoma: a 40-year experience at the University of Florida. Am J Clin Oncol. 2013;36(1):83-88.

3. Spillane AJ, A'Hern R, Judson IR, Fisher C, Thomas JM. Synovial sarcoma: a clinicopathologic, staging, and prognostic assessment. J Clin Oncol. 2000;18(22):3794-3803.

4. Thway K, Fisher C. Synovial sarcoma: defining features and diagnostic evolution. Ann Diagn Pathol. 2014;18(6):369-380.

5. Harb WJ, Luna MA, Patel SR, Ballo MT, Roberts DB, Sturgis EM. Survival in patients with synovial sarcoma of the head and neck: association with tumor location, size, and extension. Head Neck. 2007; 29(8):731-740.

6. Eilber FC, Dry SM. Diagnosis and management of synovial sarcoma. J Surg Oncol. 2008;97(4):314-320.

7. Salcedo-Hernandez RA, Lino-Silva LS, Luna-Ortiz K. Synovial sarcomas of the head and neck: comparative analysis with synovial sarcoma of the extremities. Auris Nasus Larynx. 2013;40(5):476-480.

8. Roth JA, Enzinger FM, Tannenbaum M. Synovial sarcoma of the neck: a followup study of 24 cases. Cancer. 1975;35(4):1243-1253.

9. Wushou A, Miao XC. Tumor size predicts prognosis of head and neck synovial cell sarcoma. Oncol Lett. 2015;9(1):381-386.

10. Tanaka K, Mizusawa J, Fukuda H, et al. Perioperative chemotherapy with ifosfamide and doxorubicin for high-grade soft tissue sarcomas in the extremities (JCOG0304). Jpn J Clin Oncol. 2015;45(6):555-561.

11. Rosen G, Forscher C, Lowenbraun S, et al. Synovial sarcoma. Uniform response of metastases to high dose ifosfamide. Cancer. 1994;73(10): 2506-2511.

12. Kampe CE, Rosen G, Eilber F, et al. Synovial sarcoma. A study of intensive chemotherapy in 14 patients with localized disease. Cancer. 1993;72(7):2161-2169.

13. Wu Y, Bi W, Han G, Jia J, Xu M. Influence of neoadjuvant chemotherapy on prognosis of patients with synovial sarcoma. World J Surg Oncol. 2017;15(1):101.

14. Pervaiz N, Colterjohn N, Farrokhyar F, Tozer R, Figueredo A, Ghert M. A systematic meta-analysis of randomized controlled trials of adjuvant chemotherapy for localized resectable soft-tissue sarcoma. Cancer. 2008;113(3):573-581.

15. Vining CC, Sinnamon AJ, Ecker BL, et al. Adjuvant chemotherapy in resectable synovial sarcoma. J Surg Oncol. 2017;116(4):550-558.
16. Vlenterie M, Litiere S, Rizzo E, et al. Outcome of chemotherapy in advanced synovial sarcoma patients: review of 15 clinical trials from the European Organisation for Research and Treatment of Cancer Soft Tissue and Bone Sarcoma Group; setting a new landmark for studies in this entity. Eur J Cancer. 2016;58:62-72.

17. Gopalakrishnan V, Amini B, Wagner MJ, et al. Synovial sarcoma of the head and neck: a single institution review. Sarcoma. 2017;2017: 2016752.

18. Crowson MG, Lalich I, Keeney MG, Garcia JJ, Price DL. Clinicopathologic factors and adjuvant treatment effects on survival in adult head and neck synovial cell sarcoma. Head Neck. 2015;37(3):375-380.

19. Lee N, Shin E. Treatment outcomes for patients with synovial sarcoma of the head and neck. Expert Rev Anticancer Ther. 2008;8(3): 371-373.

20. Trible WM. Destructive lesions of the sphenoid. South Med J. 1970; 63(7):849-852.

21. Cihak RA, Lydiatt WM, Lydiatt DD, Bridge JA. Synovial sarcoma of the head and neck: chromosomal translation $(\mathrm{X} ; 18)$ as a diagnostic aid. Head Neck. 1997;19(6):549-553.

22. Bettio D, Rizzi N, Colombo P, Bianchi P, Gaetani P. Unusual cytogenetic findings in a synovial sarcoma arising in the paranasal sinuses. Cancer Genet Cytogenet. 2004;155(1):79-81.

23. Gallia GL, Sciubba DM, Hann CL, et al. Synovial sarcoma of the frontal sinus. Case report. J Neurosurg. 2005;103(6):1077-1080.

24. Yildirim A, Tosun F, Alaomeroglu M. Synovial sarcoma of the nasal septum. Ann Otol Rhinol Laryngol. 2005;114(1 pt 1):84-86.

25. Kartha SS, Bumpous JM. Synovial cell sarcoma: diagnosis, treatment, and outcomes. Laryngoscope. 2002;112(11):1979-1982.

26. Subramaniam MM, Shuen CS, Petersson F. Poorly differentiated synovial sarcoma of the sphenoid sinus: report of the first case and review of synovial sarcomas of the sinonasal tract. Histopathology. 2012;61(6): 1232-1237.

27. Wong HT, Ho CY, Nazarina AR, Prepageran N. Synovial sarcoma of the ethmoidal sinus. J Laryngol Otol. 2014;128(11):1022-1023.

28. Sun J. Synovial cell sarcoma of the maxillary sinus: a first reported case. Otolaryngol Head Neck Surg. 2003;129(5):587-590.

29. Salcedo-Hernandez RA, Lino-Silva LS, Luna-Ortiz K. Maxillary sinus sarcomas: epidemiological and clinicopathological experience of 25 years in a National Reference Cancer Center. Indian J Otolaryngol Head Neck Surg. 2014;66(4):359-364.

30. Rangheard AS, Vanel D, Viala J, Schwaab G, Casiraghi O, Sigal R. Synovial sarcomas of the head and neck: CT and MR imaging findings of eight patients. AJNR Am J Neuroradiol. 2001;22(5):851-857.
OncoTargets and Therapy

\section{Publish your work in this journal}

OncoTargets and Therapy is an international, peer-reviewed, open access journal focusing on the pathological basis of all cancers, potential targets for therapy and treatment protocols employed to improve the management of cancer patients. The journal also focuses on the impact of management programs and new therapeutic agents and protocols on
Dovepress

patient perspectives such as quality of life, adherence and satisfaction. The manuscript management system is completely online and includes a very quick and fair peer-review system, which is all easy to use. Visit http://www.dovepress.com/testimonials.php to read real quotes from published authors. 